\title{
Human impacts on suspended sediment and turbidity in the River Murray, South Eastern
} Australia: Multiple lines of evidence

\author{
Ian Dingo Rutherfurd ${ }^{1 *}$, \\ Christine Kenyon ${ }^{1}$, \\ Martin Thoms ${ }^{2}$, \\ James Grove ${ }^{1,3}$, \\ Jodie Turnbull ${ }^{3}$, \\ Peter Davies ${ }^{3}$, \\ Susan Lawrence ${ }^{3}$ \\ ${ }^{1}$ School of Geography \\ University of Melbourne \\ Carlton, Victoria, Australia \\ ${ }^{2}$ Riverine Landscapes Research Lab, Geography \& Planning \\ University of New England \\ Armidale, New South Wales,Australia \\ ${ }^{3}$ Department of Archaeology and History \\ La Trobe University \\ Bundoora, Victoria, Australia
}

This is the author manuscript accepted for publication and has undergone full peer review but has not been through the copyediting, typesetting, pagination and proofreading process, which may lead to differences between this version and the Version of Record. Please cite this article as doi: $10.1002 /$ rra.3566

This article is protected by copyright. All rights reserved. 
Suspended sediment in the River Murray

Correspondence

I. D. Rutherfurd, School of Geography, University of Melbourne, 221 Bouverie Street, Carlton, Victoria, Australia 3053.

Email: idruth@unimelb.edu.au

"The muddy Murray may present some attractions to many Australians, yet I feel forced to confess that to me it was painfully suggestive of a large but dirty ditch” (River boat captain in South Australian Weekly Chronicle, Adelaide, South Australia, Saturday, May 23, 1885, p. 8).

\section{ABSTRACT}

European settlement has led to increased loads of fine suspended sediment (SS) entering the river Murray, Australia's largest, and arguably, most important river. The river Murray's anthropogenic sediment history can be divided into four periods with varying source areas, sediment loads, and seasonal patterns. The “Aboriginal period” (before 1840) was characterised by clear water at summer low flows in the river Murray and its southern tributaries, with more sediment coming from the northern catchment than the southern, and the Darling River being turbid at all flows. There is little evidence that Aboriginal burning resulted in any measurable increase in SS. SS loads peaked in the 1870s and 1880s (the "gold and gully period," 1850-1930) as valley floors were incised by gullies (mostly in northern tributaries), and gold sluicing flushed huge amounts of sludge into southern tributaries. Sedimentation in wetlands and on floodplains increased by 2-10 times in this period, and the biota in wetlands switched from clear water to turbid water communities. In the "hiatus period" (1930-1960), sediment supply from gullies and gold mining waned and low flow SS concentrations returned to low levels. Dam construction through the 1960s and 1970s (the "regulation period," 1960 onwards) disconnected the river Murray from catchment-derived sediment. Despite this, SS levels increased again: now largely derived from instream sources including bank erosion from long- 
Suspended sediment in the River Murray

duration summer irrigation flows, the spread of bottom-feeding carp (Cyprinus carpio), and wave erosion from boats. Erosion switched from winter to summer dominated. Significant investment in securing water for the environment in the Murray-Darling Basin could be complemented by addressing in-channel sediment sources in the river Murray itself to reduce turbidity. Overall, European era SS concentrations remain relatively low with small sediment delivery to the ocean $(0.1$ $\mathrm{M} \cdot \mathrm{t} \cdot \mathrm{a}^{-1}$ ), despite high catchment erosion rates. This is due to poor sediment delivery efficiency through the low-gradient landscape.

\title{
KEYWORDS
}

\author{
Australia \\ human-impact \\ regulation \\ river \\ river Murray \\ sediment load \\ suspended sediment \\ turbidity
}

\section{INTRODUCTION}

The Murray is Australia's largest river in terms of discharge and combined with its major northern tributary, the Darling River, has a basin area of 1.07 million km². It is Australia's most important river system economically, and its environmental condition is of national importance. This has been demonstrated in the \$A10 billion committed to recovering environmental water in the basin since 2010 (Hart, 2016). A comprehensive review of the condition of rivers within the Murray-Darling Basin (MDB, Norris et al., 2001) concluded that "suspended sediment loads are the greatest contributors to river degradation [in the Basin].” Fine suspended sediment (SS) is also related to high 
Suspended sediment in the River Murray

nutrient levels in the river, particularly phosphorus (Olley, 1995), and heavy metal loads (Thoms, 2007). It is common for older people to describe the river Murray of their childhood when the water always seems to have been transparent and when children could see crayfish scuttling across the sandy river bottom (Sinclair, 2001). This river of their childhood is perceived to be gone, replaced with a permanently turbid, "muddy” river. Such perceptions of the river are critical for shaping management and stream restoration goals and for understanding community expectations for this iconic river. Gell and Reid (2016) have argued that the major ecological emphasis for restoration and protection of the river Murray has been too focussed on issues of water volume, rather than on water quality concerns: They particularly refer to sediment, salt, and nutrient concentrations.

Considerable work has explored different aspects of the sources, volumes, and deposition of SS in the river Murray catchment and channel (reviewed below), but the record of SS concentration (SSC) measurement on this river is poor. Even turbidity (a poor surrogate for water clarity; Davies-Colley \& Smith, 2001) has been routinely measured at only a few sites since 1978 (Mackay et al., 1988). However, there are numerous historical and anecdotal reports about water quality in the river that extend the record. In the 1990s, work on sediment loads and deposition rates for the lowland section of the river Murray was undertaken (Thoms \& Walker, 1992; Thoms, 1995; Thoms et al., 2000), and these have been supplemented with reconstructions of water quality from palaeolimnological studies on wetlands (Ogden, 2000; Gell et al., 2007; Reid et al., 2007; Gell et al., 2009; Reid \& Ogden, 2009). In the 2000s, detailed sediment budgets were developed from a series of catchment models (Hughes \& Prosser, 2003; Prosser et al., 2003; DeRose et al., 2004; Moran et al., 2005; Lu et al., 2006). Most recently, isotopic techniques have added to our knowledge of the post-European history of SS in the river Murray (Gingele \& De Deckker, 2005, Dosseto et al., 2006).

Despite the large body of information about the most visible of water quality parameters, there has been no comprehensive synthesis of the impact of humans on SS in the river Murray, although there has been on the Murrumbidgee River (Olley \& Scott, 2002). In this paper, we draw on multiple lines of evidence to reconstruct a history of SS in the river Murray. We consider the 2,500-km section of the lowland river from Albury to the river mouth. We synthesise recent work on Aboriginal and postEuropean (here defined as post-1840s) sediment loads, deposition rates, and sediment delivery rates to the ocean. Wherever possible, we attempt to consider the true mineral SS (typically fine sands, silts, 
Suspended sediment in the River Murray

and clays), but evidence is often from anecdotal reports of water clarity, optical measures of turbidity, and measurements of total suspended solids, which can also include substantial organic material. Similar reconstructions have been attempted on the Yangtze (Wang et al., 2008), Mississippi (Meade \& Moody, 2010), and Rhine Rivers (Asselman, 1999). This manuscript also contributes to a growing literature that attempts to extend detailed records of human impact beyond the instrumental record (Gale \& Haworth, 2002; Gillson \& Willis, 2004; Butzer \& Helgren, 2005). The paper complements reviews of human impacts in the MDB concerned with biological condition (Davies et al., 2010) on vegetation and land use (Lunt, 2002), wetlands (Gell \& Reid, 2014), and river flow (Gallant \& Gergis, 2011).

Detailed knowledge of changes wrought by humans assists in understanding our landscapes and in defining targets for management and restoration. The review begins with a chronological assessment of the history of sediment sources based on descriptions and measurement. We then consider where that fine sediment has been deposited. Finally, we turn to modelling and isotopic methods that attempt to synthesise sediment sources and sinks in the river Murray and its floodplains. The overall aim is to summarise the spatial and temporal phases of human impacts on SS in the river Murray and place this in an international context. Although we touch on the consequences of changing SS loads and concentrations, and on erosion and deposition, this is not a central purpose of this review.

\subsection{Description of the Murray-Darling Catchment}

The MDB, the largest Australian river basin, drains 14\% of Australia's landmass (Figure 1). The river Murray has a catchment area of 310,000 $\mathrm{km}^{2}$ above the Darling River confluence and drains mostly the south and south-eastern part of the basin (temperate and alpine climates, respectively, winter rainfall dominated). By comparison, the Darling River drains the subtropical north (summer rainfall dominated), with an average annual rainfall showing a strong regional gradient from $>1,000 \mathrm{~mm}$ along the Great Dividing Range in the east, to as little as $180 \mathrm{~mm}$ in the arid west. The result is that both seasonal and annual stream flows in the basin are highly variable. At Blanchetown, $274 \mathrm{~km}$ upstream from the mouth of the Murray, annual discharges for the period 1950-1998 ranged from 6 to $519 \mathrm{~m}^{3} \mathrm{~s}^{-1}$ (mean $318 \mathrm{~m}^{3} \mathrm{~s}^{-1}$ ). Flows in the Murray-Darling system are regulated by a series of 21 headwater dams and over 8,000 low-head weirs (including 12 weirs along the course of the Murray 
Suspended sediment in the River Murray

itself). The Murray meets the Darling $830 \mathrm{~km}$ upstream from its mouth, and there are no significant tributaries to the Murray below the Darling junction.

Most tributaries of the MDB originate in the Great Dividing Range at elevations below 2,000 m. Their river long profiles have short, steep gradients in the headwaters and much longer low gradient for the rest of the river course. The lowland river Murray and its tributaries are low energy (bed slopes range from $1 \pm 2 \mathrm{~m} \mathrm{~km}^{-1}$ to $0.2 \mathrm{~m} \mathrm{~km}^{-1}$ ), meandering river systems with extensive floodplains with many palaeochannels and oxbow lakes (called billabongs in Australia and in this paper). There are major distributary systems with numerous anabranches. The central and western parts of the Murray Basin consist of Cenozoic sands, silts, and clays deposited as a result of alluvial and aeolian processes. Thus, rivers carry mainly fine sand, silt, and clay in suspension. In general, the Darling River carries smectite-rich clays, whereas other tributaries carry illite-rich clays (Gingele \& De Deckker, 2005). The rivers of the MDB are highly modified, and flows are highly regulated. We will not expand on these impacts here but invite readers to see a useful review in the introduction of Gell and Reid (2014). There are reviews of human changes to biological systems (Davies et al., 2010), floodplains (Reid et al., 2002), wetlands (Gell \& Reid, 2014), and water development (Leblanc et al., 2012) of the MDB. In this manuscript, we focus on the river Murray downstream of Albury, and we call this the “middle Murray” down to the Darling River junction, below which is the "lower Murray."

\section{CHRONOLOGY AND DESCRIPTION OF HUMAN IMPACTS ON SS IN THE RIVER MURRAY}

Human impacts on SS in the river Murray can be broken into four periods:

- $\quad$ Aboriginal period (before 1840),

- $\quad$ the gold and gully period (1850s to 1930s),

- $\quad$ hiatus period (1930s to 1960s), and the

- $\quad$ regulation period (1960s to the present).

The chronology of some human impacts in these periods are summarised in Table 1 and discussed in detail below.

This article is protected by copyright. All rights reserved. 


\subsection{Aboriginal period (pre-1840s)}

This review concentrates on the influence of humans on SS. Humans have occupied the river Murray catchment for at least 40,000 years (Bowler et al., 2003). This section explores the substantial changes in river character over this period and whether humans had any measurable impact on SS in the river Murray before European invasion.

\subsubsection{Late Quaternary river morphology and sediment character}

During the last glacial cycle, from 105 to 13 ka, snow-melt fed rivers of the Riverine Plains (Reinfelds et al., 2014) that were substantially larger in planform and cross-section and bedload (gravel) dominated (Page et al., 2009) with bankfull discharges of 3-11 times those of the present (Holocene) rivers (Kemp \& Rhodes, 2010). Thus, more humid Holocene climates reduced flood peaks and reduced the sediment supply from a now vegetated upper catchment. Streams changed from large, meandering, bedload-dominated channels, to smaller sinuous, SS forms (Page et al., 2009; Prendergast et al., 2009). Thus, between 12 and 7 ka, these large channels incised a few metres and dramatically reduced their dimensions to "suspended load channels dominated by slow muddypointbar and counterpoint sedimentation. Fine-textured sedimentation of levees and infilling older channel networks” (Kemp \& Rhodes, 2010, p. 749). Sediment residence time in the fluvial system decreased in the period from 100 to $15 \mathrm{ka}$ and increased from $15 \mathrm{ka}$ to the present (Dosseto et al., 2010). Note that this description could give the impression that Holocene rivers had higher SSC than the Late Pleistocene rivers, but that cannot be inferred from the evidence. It is more likely that with the waning water and sediment discharge coming into the Holocene, there has been less SS in transport, but more of it is deposited.

\subsubsection{Human impacts on sediment (pre-1840s)}

Humans have been modifying the landscape of the MDB for at least 40,000 years, predominantly through fire regimes to manage vegetation and resources. Elsewhere, land practices of indigenous peoples have led to substantial erosion and valley-floor deposition (see review in Portenga et al., 2016). We could find no studies of this topic within the MDB, so we have reviewed related literature from elsewhere in Australia. Through the 1980s, there was a debate about whether Aboriginal burning 
Suspended sediment in the River Murray

explained an increase in Late Holocene deposition rates in the uplands of south east Australia (Hughes \& Sullivan, 1981), but a review of the data by Prosser (1990) concluded that "An increase in fire frequency beginning at 3,000-4,000 yrs BP, as a result of intensified Aboriginal burning, did not change the mechanisms or rates of denudation nor did it cause widespread alluviation as suggested by others” (p. 77). Prosser's conclusion appears to be supported by subsequent work. Bowman (1998) reviewed the consequences of Aboriginal burning in northern Australia and concluded that there was little evidence of widespread increase in erosion related to burning: "This impact should be recorded in the sedimentary record, but it is not” (p. 402). Portenga et al. (2016) used the ${ }^{10} \mathrm{Be}$ isotope to conclude that aridification due to climatic cooling (Gingele \& de Deckker, 2007) and an intensification in El Niño-Southern Oscillation activity (Lynch et al., 2007) led to environmental change c. $45 \mathrm{ka}$, rather than the earlier view; this was due to the immediate impact of Aboriginal arrival and burning practices. This view has been supported by a subsequent study using isotopic measures of erosion rates in the southern New South Wales (NSW) Tablelands (Portenga et al., 2016), where there is archaeological evidence for Aboriginal presence from c. 21 ka. They identified an increase in the frequency of low-intensity fires between 3,000 and 1,000 years BP at a time of increased population numbers with permanent habitation of the Tablelands region. El Niño-Southern Oscillation activity also intensified at this time. They conclude that this activity did not alter the millennial-scale erosion rates. Gale and Haworth (2002) came to a similar conclusion from evidence in the NE NSW Tablelands, finding low erosion and deposition rates from Aboriginal landscapes between 12.3 and $5.6 \mathrm{ka}$.

We conclude that if Aboriginal land-use practices increased erosion rates, it was likely to be modest and is not likely to have resulted in measurably changed SS loads in the river Murray. Thus, we consider the water quality, with respect to sediment load, of the rivers observed by first European explorers to have been largely unaffected by humans.

\subsubsection{Early European descriptions of the river}

Cattle and sheep have grazed the catchments of the river Murray as early as the 1830s. The records of early explorers and settlers often describe the clarity and colour of water in rivers. Here, reports prior to 1840 are considered to reflect a pre-European impact catchment. 
Suspended sediment in the River Murray

Early 19th century descriptions of the MDB rivers consistently describe clear flowing water over sandy, pebble, or gravel beds (Oxley, 1818; Hovell \& Hume, 1824; Sturt, 1833; Stapylton, 1836; Sturt, 1838; Mitchell, 1839). Muddy or “turbid” floodwaters (Sturt, 1833; Mitchell, 1839; Wilson, 1859) spread across wide flat alluvial plains taking several weeks to pass downstream (Curr, 1965). These characteristics of the river Murray were described by river travellers (Finniss, 1853; Kinloch, 1856; Jevons, 1859; Wilson, 1859; Brady, 1911), settlers (Beveridge, 1883; Curr, 1965), and surveyors (Hodgkinson, 1856; Harris, 1938; Broughton, 1966). On the basis of reports from the 1820s, Scott (2001) similarly concluded the lower Murrumbidgee and Macquarie Rivers were "transparent" during low flows, but not during floods, and that the waters of the Lachlan and Darling Rivers were typically turbid.

In 1824, Hamilton Hume and William Hovell, the first Europeans to encounter the river Murray ("Hume” River) near the modern town of Albury reported that "in general; the water for so considerable a current was clear" and "the bed of the ['Hume'] river, was in general composed of sand containing a good deal of mica” (Hume, 1831) but near what is now Howlong, the river was wider, the banks steep, and bank erosion had caused large trees to fall into the river (Hovell \& Hume, 1824). The overlander, George Hamilton, in January 1838, also described a clear, fast-flowing river with a sandy bed near the modern town of Corowa and described the high eroding banks (Hamilton, 1845).

George Augustus Robinson, the Victorian Aboriginal Protector, described the Hume River upstream of the Ovens River: "The bottom of the river at the fording place was hard and gravelly ... The water is clear and good” (Clark, 2000). Through what is now known as The Barmah-Millewa Forest, Sturt (1838) described the Bullatale Creek effluent as deep, its waters "a dark colour and earthy in taste” probably due to the waters passing through extensive reed beds at the offtake. In March 1843, G. A. Robinson compared the Murray and Goulburn Rivers: The "remarkable appearance of the Goulburn \& Murry River: Viz Goulburn water, where Murry joins at the junction, is black or dark brown; the Murry [sic] green"(Clark, 1988). The upstream Goulburn River waters were described by Hamilton (1845) as “yellowish-white.”

Downstream of the Murrumbidgee River, Charles Sturt (1828-1829) entered what he described as the “Mighty Murray” where “the water was 'transparent,' running over a sandy bed” (Sturt, 1833, p. 
Suspended sediment in the River Murray

82). Major Thomas Mitchell's party, in May 1836, described the Murrumbidgee River waters, near the river Murray junction as being "quite clear": This clarity may have been due to the saline springs in the channel bed. A few weeks later, upstream from Swan Hill near the modern town of Cohuna, Mitchell initially described "clear water” in the River Murray, its anabranches, and billabongs (Stapylton, 1836; Mitchell, 1839), but as the floodwaters rose, these filled with the "clay-coloured water of the flood then in the Murray."

To summarise these descriptions at the first European settlement, the river Murray had low turbidity (usually described as being "clear") at all times except during high flows. The same was true of all of the southern tributaries (Figure 1) and the Murrumbidgee River in the north. Typically, summer flows were described as slow, water levels were low, and the water described as clear, transparent, "translucent," or "sweet.” The waters of the river Murray and its tributaries were filtered through large reed beds that sometimes led to dark (organic stained) and green water at low flows. Billabongs were clear but became turbid during floods. The river Murray below the Darling River appears to have been turbid for most of the time, even at low flows.

As we discuss below, palynological evidence supports the proposition that, at first European contact, the waters of the wetlands, billabongs, and terminal lakes of the river Murray were generally clear with dense stands of submerged macrophytes (Ogden, 2000; Gell et al., 2006; Reid et al., 2007). Sturt (1833) described stands of reeds along the river and floodplain as he approached the terminal lakes.

\subsection{The gold and gully period (1850s to 1930 s)}

The 1850s represents the beginning of major European activities within the river Murray catchment (Sturt, 1833), with an increase in sediment delivery to the river. At the beginning of the gold rush in March 1851, Victoria's European population was 77,000, and by 1861, it had increased to 540,000 (Bate, 1988). This population growth coincided with a correspondingly large increase in clearing, burning, stock grazing, and cropping. The river Murray channel itself began to be altered by removing 
Suspended sediment in the River Murray

the large dead trees (desnagging), initially to improve navigation, but later to more quickly pass flood and irrigation waters.

\subsubsection{Sediment from catchment erosion and gullying}

Numerous studies have established that European settlement in the river Murray catchment coincided with a phase of incision into upland valley fills by gullies between the 1850s and 1930s (Portenga et al., 2016). Although gullying was associated with land clearing, the major cause appears to have been disturbance of vegetation and concentration of flow in the valley floors themselves (Prosser \& Slade, 1994). Using isotopes, Wallbrink et al. (1998) demonstrated that more than $80 \%$ of the post-European sediment in the Murrumbidgee catchment was derived from gullies and river channel erosion and just $20 \%$ from erosion of slopes and agricultural land. In the Murrumbidgee catchment, those subcatchments with the highest sediment yield are also those catchments that have a high gully density (DeRose et al., 2003). Sediment production from gullies last a few decades and increased sediment supply to floodplains and channels by two orders of magnitude (Wasson et al., 1998; Olley \& Wasson, 2003). Gullying led to widespread deposition of fine sediment on upland floodplains, labelled post-European settlement alluvium (Portenga et al., 2016).

It is well recognised that European occupation initiated gullying in the MDB. Less well recognised is the sometimes catastrophic effect of gold mining on the geomorphology and water quality of the river Murray and its tributaries, particularly the Victorian tributaries (Upper Murray, Kiewa, Ovens, Campaspe, and Loddon Rivers; Davies et al., 2018). There was also substantial historical gold mining on the NSW inland slopes in the headwaters of the Murrumbidgee, Lachlan, and Upper Murray tributaries. In 1852, Alfred Howitt described Nine Mile Creek (a tributary of the Ovens River): "The trees were cut down by thousands and the course of the creek was laid bare for miles" ... "the discoloured water running down the creek" ... "[the creek] had been dugout again and again, and had been sluiced three times” (Howitt, 1913, p. 12).

Gold mining was associated with direct flushing of sludge into waterways, the burning and clearing of forests, and intensifying agriculture, leading to coincident erosion and gullying. From the beginning 
Suspended sediment in the River Murray

of the gold rush in 1851, until the decline of bucket dredging since the 1920s, streams in the catchment of the river Murray were subjected to erosion and deposition from successive waves of mining, each using different technologies (Davies et al., 2018; Figure 2). "Sluicing,” between 1865 and 1870, delivered the most sediment to the streams producing sediment concentrations of between 8,400 and 14,000 ppm (Davies et al., 2018). Later technologies (such as hydraulic jets) produced more sediment per mine site, but there were much fewer sites. In 1903, it was noted that "The chief cause of discolouration of the River Murray above Albury ... is probably due to hydraulic sluicing carried out in the ... Mitta Mitta ... Kiewa ... and [Ovens] in the vicinity of Beechworth" (Sellars, 1903). River Murray and tributary waters were often described as having the "consistency of pea soup,” turbid, “murky,” and “yellow” (Lloyd \& Nunn, 1987). Sediment pollution from tailings on alluvial flats (Lloyd \& Nunn, 1987) was a major preoccupation of the gold era: Victorian government inquiries and Royal Commissions into "the problem of sludge" occurred in 1859, 1861, 1872, 1887, and 1914 (Lawrence \& Davies, 2014). Increased government regulation by the Sludge Abatement Board, combined with declining mining, and gully stabilisation led to declining sediment supply by the 1930s. By the 1940s, dredgers were strictly controlled and many worked in closed water systems or filtered their sediment-laden water (Dickinson, 1939). Although the gold yield gradually fell over time, the total volume of sediment liberated into streams increased dramatically between 1850 and 1870, then fell gradually to the 1890s and into the early 20th century (Figure 2).

SS delivery efficiencies for gold-mining were high in the upper tributaries where few large dams trapped the sediment: "Beyond Tintaldra the water from Tumbarumba comes in, laden with the silt of mining. Above this confluence the Murray is a clear and narrow stream, but the tributary water doubles its volume and makes all turbid” (The Sydney Morning Herald, NSW; Saturday, May 26, 1894, p. 5). Early dams, such as Laanecoorie on the Loddon River, quickly filled with sediment (McCoane \& Murray, 1906). No other large dam in Victoria has filled with as much sediment as Laanecoorie (Davis et al., 1997). Whenever water was available (usually winter and spring), numerous mining processes would wash sediment directly into the channel. Measurements of SSC by the Sludge Abatement Board of Victoria dating from 1906 to 1919 are possibly the earliest water quality measurements in the MDB (Figure 3). These figures demonstrate that hydraulic sluicing produced two to three orders of magnitude increases in sediment concentrations in the Ovens River in 
Suspended sediment in the River Murray

the early 1900s (Figure 3); there are many descriptions of this discoloured water reaching the river Murray: "To prove further that the slum is still from the alluvial workings, as was the case 20 or 25 years ago, it is only necessary to compare the waters of the King and Ovens rivers at the point where the King joins the Ovens. The water from the King is clear, and without any touch of discoloration other than is usual in a mountain stream. That of the Ovens is 'pea-soupy' and thick. ... It is only fair to point out that Mr. Diffoy stated that the water was much less objectionable than when hydraulic sluicing was in full swing [in the 1860s and 70s]" (Ovens and Murray Advertiser, Beechworth, Victoria, Saturday, November 14, 1903, p. 8). From a fisheries of NSW annual reports, "The Corowa Anglers' Club, report that the waters of the River Murray were being polluted to such an extent by mining operations on the Mitta Mitta and Kiewa Rivers (Victoria) as to cause the destruction of fishlife ... The discharge from the mines discoloured the River Murray down to Echuca” (Adelaide Advertiser, May 2, 1907). However, a large proportion of the fine sediment was deposited on floodplains, sometimes in deposits over 2-m thick (Peterson, 1996), and it is likely that only a small proportion of the sediment would have reached the river Murray.

Mining would often stop in summer due to lack of water (Davies et al., 2011). During floods, sediment would also be washed from tailing piles and failed sludge dams into river channels. "The Minister of Mines ... visited Wangaratta on Friday, for the purpose of inspecting the junction of the Tarrawingee sludge channel with the Ovens River, where a vast accumulation of silt has taken place, to the detriment of the river course and adjoining properties” (The Age, Melbourne, Victoria, Saturday, February 15, 1919, p. 14). So, mining differs from natural sediment patterns in that it delivers sediment at low winter flows, not just during floods, and turbidity would tend to decrease downstream, whereas modern loads tend to increase (Figure 7). Summer flows would be less affected, but sludge was transported when the river rose: “Although, in the Upper Murray, in summer even when water levels were low the water at Albury was dirty and, after freshets the water got very thick, indicating that the sludge was brought down quicker." And "Even the same volume that found its way into the Murray from the Kiewa River would cause serious pollution in the summer” (Ovens and Murray Advertiser, Beechworth, Victoria: 1855-1918, Saturday, July 21, 1906, p. 10).

The gold mining phase coincides with the gullying phase (1850 to 1930), and both sediment sources would have contributed to increased SS loads in the river Murray in both winter and summer. It is 
Suspended sediment in the River Murray

likely that gold mining released a comparable amount of sediment to streams as did catchment erosion and gullying (Rutherfurd et al., 2016). Despite low delivery efficiencies, we propose that the combined mining and gullying periods of the 1860s to 1890s, represent the period of highest European-derived sediment delivery to the river Murray and sediment supply from both sources had tailed off by the 1930s.

\subsubsection{Palaeolimnological evidence for a late 1800s increase in SS}

Palaeolimnological evidence from billabongs, along the river Murray, support the proposition of a mid-late 19th century increase in river turbidity. Ogden (2000) used the first presence of Pinus pollen, in billabong sediments, as a temporal marker for the beginning of European activity on the river Murray floodplain. At the same depth, he recorded a change from phytophilous to pelagic Cladoceran families from which he inferred the loss of billabong plant macrophyte communities. He concluded that the macrophytes, which are an indicator of relatively clear water, disappeared between the late 1800s and the 1930s due to increased turbidity. Reid et al. (2007) corroborated this finding in other river Murray billabongs and argued for a synchronous period of high turbidity and a doubling of sediment deposition rates towards the end of the 1800s that substantially altered the biology of billabongs along the river. Gell et al. (2006) found a very similar pattern of increased mid to late 1800s sedimentation (10-30 times over pre-European rates) in the lower lakes of the river Murray, coupled with a shift in wetland trophic state from submerged macrophytes in clear waters to phytoplankton-dominated, turbid systems. They suggest that deposition rates had declined by the 1920s.

\subsection{Hiatus period (1940s to 1960 s)}

Sediment supply from both gullying and gold mining declined from the 1930s and appear to have reached a minimum from the 1940s to the 1960s. There are reports of high sediment yields from the 1930s, particularly due to erosion below the Hume Dam after it filled with water and became operational in 1936. A newspaper reported in 1940 that "Repeated concern has been expressed quite freely in the Albury Wodonga districts during the past few years over the relentless erosion which has been attacking pastoral properties along the Murray's banks, on both sides of the river just downstream from the Hume Dam” (W.H. Pentreath-Kinsela, Chronicle, Adelaide, South Australia, 
Suspended sediment in the River Murray

Thursday, January 25, 1940, p. 49). Nevertheless, there are numerous recollections of the river Murray from the 1930s through to the 1960s, from people still alive today, that describe a river that resembles those described by the first European explorers, with clear water at low flows. They also commonly state that the modern river is now much more turbid. For example, "The situation before the advent of the Hume [Dam] ... although discoloured at flood time, the water [in the Murray] was extremely clear, and the bottom could be seen at 6 to 8 feet” (Cadwallader \& Rogan, 1977). Don Briggs (born 1937) of Shepparton, a Yorta Yorta elder, describes the 1940s river Murray: "Into my teenage years well the river was green and clear, you could see the logs in 10 to 15 foot in the water. Now you can't see that” (Trueman, 2011). In the mid-1950s, as a child, Wally Cooper remembers the river Murray from Yarrawonga to Echuca as "the river was so clean. It was a massive, beautiful, clean river. You could see through the water and you could see better in the deep part than you can today. And you could probably see fifteen feet in front of you when you were diving down” (Frawley et al., 2011). Sinclair (2001) also records numerous anecdotes of a clear river: "Even though the river varied considerably in its clarity, depending on the time of year and the condition of its tributaries, it is common for people to remember the water of the Murray looking clear and tasting sweet. It was common for travellers up until the mid-1960s to describe seeing fish swimming in the water” (p. 98).

\subsection{The flow regulation period (1960s to the present)}

Since the 1970s, a ring of large dams constructed on tributaries (Figure 1), with high trap efficiencies, has essentially disconnected the River Murray from its catchment. Only the Ovens River does not have a major dam (although it has large dams on its tributaries on the King and Buffalo Rivers). These dams store water for irrigation so, since the 1970s, the river between the Hume Dam and Yarrawonga Weir has experienced steadily increasing durations of summer-irrigated flow releases from Dartmouth and Hume Dams (Maheshwari et al., 1995). Over summer, the river can run at bankfull flows (around $230 \mathrm{~m}^{3} \mathrm{~s}^{-1}$ ) for more than 3 months of the year. There is substantial evidence that these irrigation flows erode the river banks and effluent channels of the river Murray and have become a dominant source of sediment to the river.

Analysis of historical cross-section surveys from Albury to Yarrawonga by Erskine et al. (1993) revealed that the river widened between 1977 and 1992 at an average rate of 160 mm year $^{-1}$. 
Suspended sediment in the River Murray

Widening occurred in straight reaches as well as on bends. The long-duration irrigation flows have also eroded the multiple effluent channels of the floodplain. This is particularly the case in the upper river (Hume Dam to Tocumwal) where water can enter unregulated effluent channels. Below Hume Dam, several effluent channels have enlarged dramatically (Erskine et al., 1993). Erosion from regulated flows is also substantial through the Barmah-Millewa Forest section of the river (Gippel \& Blackham, 2002).

This dominance of in-channel sources was noted by Thoms and Walker (1992) who suggested that over $69 \%$ of the average annual sediment load is derived from in-channel sources, and during irrigation flows, this rises to nearly $80 \%$ (Figure 4). In the river Murray, sustained discharges at or near channel capacity dominate the sediment regime. However, note that more of the sediment in the river Murray is now transported during the summer months, when the long-duration irrigation flows take place, whereas in the less-regulated tributaries, most of the sediment is transported during the winter months (Thoms \& Walker, 1992).

The effect of riverbank and effluent erosion can be seen by comparing turbidity data at Tocumwal and Cobram (Figure 5). These two stations are located upstream of Barmah Forest, are separated by 40 river kilometres, and have no tributaries entering between them. Yet the turbidity between these stations in the $>60,000 \mathrm{Ml}^{\text {day }}{ }^{-1} 1992$ flood nearly doubles. This suggests that turbidity is coming from bank erosion and erosion of effluent channels.

Over the last 17 years, more than \$A25 million has been spent on physical works to protect the banks of the river Murray from erosion associated with flow regulation and boat wave wash, between the Hume Dam and Yarrawonga (Murray-Darling Basin Authority, 2017). Substantial erosion has also occurred in the lower Mitta Mitta River below Dartmouth Reservoir due to long periods of summer irrigation flow (Green, 1999). The rate of this erosion is falling as the length of the Mitta Mitta River is progressively protected with rock revetment.

Bank erosion by high energy waves of $\sim 50 \mathrm{~cm}$ generated by water-skiing and wake-enhancing boats (Figure 6) is another source of SS in the river Murray between Albury and Yarrawonga, with the highest rates around Corowa (Roads and Maritime Services, New South Wales, 2017). The water skiing season coincides with the stable, long-duration, high summer irrigation flows, so that vessel waves exacerbate erosion by the regulated flow, eroding a notch in the silt and clay bank (up to 7.6 
Suspended sediment in the River Murray

mm day ${ }^{-1}$ ) and increasing summer turbidity levels (Roads and Maritime Services, New South Wales, 2017).

Note that the sources of sediment in the Murrumbidgee River might be very different. Based on just 2 years of SS data (1991 and 1992), Olive and Olley (1997) found much higher total suspended solid concentrations in the Murrumbidgee than the Murray and that the source of sediment was not erosion of the main channel, but erosion of tributaries.

\subsubsection{The contribution of carp to SS}

It is commonly held that invasive fish have increased turbidity in the MDB. Goldfish were reported in the Barmah region in 1873 (Castlemaine Mail, April 26, 1873), and by the 1930s, they were present in large numbers in the Central River Murray (Trueman, 2011). European carp (Cyprinus carpio), first introduced into the rivers of the MDB in the 1900s, had a rapid population increase after the 1960s. They were spread particularly by the 1973 flood and by 1976 had begun to invade reaches between Yarrawonga and Hume Dam (Walker \& Hillman, 1977). European carp are now the most abundant large freshwater fish in south east Australia (Koehn et al., 2000) comprising more than $90 \%$ of the total fish biomass in many areas, with biomasses as high as $3,144 \mathrm{~kg} \mathrm{ha}^{-1}$. Although much of the Australian research has focussed on floodplains and shallow lakes, a review of the influence of European carp in Australian rivers suggests that carp affect turbidity by their specialist feeding technique of sieving through the substrate of the riverbed (Vilizzi et al., 2014; Koehn et al., 2016) especially where flow is slow (Koehn, 2004; Koehn et al., 2016). Significant increases in billabong turbidity can occur at carp densities of 50-75 $\mathrm{kg} \mathrm{ha}^{-1}$ (King et al., 1997) with noticeable shifts from a clear water to turbid water state at densities of $200-300 \mathrm{~kg} \mathrm{ha}^{-1}$. These densities are frequently exceeded in rivers and wetlands of the MDB. The influence of carp will be greater during low flow periods than during flood events. Most studies of carp turbidity have been carried out in lentic conditions and behind weir walls, so their influence in flowing water is less certain. Nevertheless, we conclude that carp almost certainly increased base flow turbidity throughout the river Murray and its floodplain wetlands since the 1970s. The routine measurement of turbidity only began in 1978, so the effect of carp cannot be isolated from other impacts on turbidity. 
Suspended sediment in the River Murray

To summarise, following a few decades of low sediment loads during the hiatus period (1930s to 1950s), by the 1960s, the SS loads again increased in the river Murray. An intense period of dam building in the 1960s and 1970s have disconnected the river Murray from its catchment so there has been a shift from catchment sources of SS to three instream sources: river bank erosion caused by more intense irrigation flows, the invasive European carp, and an increase in water skiing. These trends can be explored in turbidity data that extend from the late 1970s.

\subsubsection{Trends in measured turbidity in the river Murray 1978 to 2012}

There are limited detailed SS data for the river Murray. The Murray-Darling Basin Authority monitors water quality under a water quality monitoring program, with nine water quality variables measured, but SS or suspended solids is not amongst them. Instead, we rely on turbidity as a surrogate, measured only since 1978. The data of Henderson et al. (2013) show an unequivocal gradual downstream increase in turbidity (from 5 to 50 Nephelometric Turbidity Unit) in the river Murray between Jingellic (above the Hume Dam) down to Morgan in South Australia (Figure 7). The data in Figure 7 also show that upstream of Swan Hill the turbidity increased by 2-3\% per year between 1978 and 2012 but has decreased downstream of Swan Hill. We would argue that the increasing turbidity is related to increasing instream erosion in the heavily regulated upstream channels. The fall in turbidity below Kyalite is almost certainly associated with inflows of higher salinity water that flocculate the suspended clays (Mackay et al., 1988).

\subsection{Deposition of SS along the river Murray}

So far, we have considered sources of SS to the river Murray. We have identified that historical descriptions suggest that sediment supply to the river peaked in the gold and gully period from the 1850s to the early 1900s, reduced from the 1930s to the 1960s, after which it increased again. In this section, we consider deposition of that sediment. Catchment modelling (described below) suggests high rates of sediment storage through the stream network, so only a small proportion of eroded sediment reaches the main stem of the river Murray, and even less reaches the ocean. Sediment can be stored in the channel bed (particularly at low-level weirs), on benches, but particularly on floodplains and in their associated wetlands. Several studies have measured storage of SS along the floodplain of the river Murray and its wetlands. Gell et al. (2009) have summarised deposition rates in nine 
Suspended sediment in the River Murray

wetlands along the river Murray (all downstream of the Murrumbidgee Junction) and three in the terminal lakes. The sediment cores did not display any clear stratigraphic marker of a shift to European period sediments, but this point could be identified by the first appearance of exotic pollen, along with isotopic signatures. The typical pre-European settlement sedimentation rates were consistently between 0.1 and $1.0 \mathrm{~mm}$ year $^{-1}$. All billabong and wetland sites experienced at least a doubling of deposition rates post-European settlement, but the average was around four times. There is no particular change in deposition rates downvalley, except that rates in terminal Lake Alexandrina and the Coorong were higher, with one to two orders of magnitude increase. The data of Fluin et al. (2007) suggest sediment accumulation rates in the terminal lakes for recent sediments, ranging from

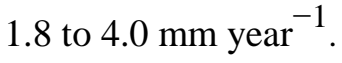

Accumulation rates in billabongs and wetlands could be expected to be higher than on the floodplain surface itself. Measurements of deposition rates on floodplain surfaces yield a less consistent story. Thoms (1995) was the first to estimate deposition rates on a floodplain within the Barmah Forest, finding high post-1954 rates of sediment deposition of $24 \mathrm{~mm}_{\text {year }}{ }^{-1}$.

Kenyon and Rutherfurd (1999) also estimated the average post-European deposition rate in the Barmah Forest using the appearance of exotic pollen at a depth of around $10 \mathrm{~cm}$. Assuming that exotic pollen would have been introduced into the forest in 1845, this suggested a deposition rate of just $1 \mathrm{~mm}$ year $^{-1}$. However, the exotic pollen is more likely to have arrived a century later, in the 1930s or 1940s, suggesting a deposition rate three times as rapid, around $3 \mathrm{~mm}_{\text {year }}{ }^{-1}$, which is comparable to the rates proposed in the Gell et al. (2009) review, but still an order of magnitude lower than estimated by Thoms et al. (2000). More recent sediment cores from Gower's Gate, on the southern edge of the Barmah Forest, analysed by one of the authors of this paper (Kenyon) suggest the following:

- $\quad$ pre-1840 deposition rate of approximately $0.8 \mathrm{~mm}_{\text {year }}{ }^{-1}$,

- $\quad 1840$ to 1890 deposition rates increasing around 10 times to 4.3 to $6.7 \mathrm{~mm}^{-1}{ }^{-1}$, and

- $\quad$ then, after 1890 , deposition rates halved to between 1.2 to $3 \mathrm{~mm}_{\text {year }}{ }^{-1}$. 
Suspended sediment in the River Murray

This pattern supports the earlier proposition that sediment loads from mining and gullying declined towards the end of the 1800s.

Deposition rates during events have also been measured. A 1996 controlled flood release from the Hume Dam provided the opportunity for Thoms et al. (2000) to measure sedimentation rates on a 2-3 km wide and $15 \mathrm{~km}$ long floodplain near the South Australian border. Floodplain deposition rates ranged from an average 0.001 to $1.94 \mathrm{~kg} \mathrm{~m}^{-2}$. This amounted to 23,200 t of sediment being deposited on the entire floodplain surface, which was equivalent to $28 \%$ of the SS flux along the study reach, or $3.8 \%$ of the total sediment input. In general, the accumulation of sediment decreased sharply with distance from the river channel.

To summarise, deposition rates of SS (sand to clay fraction) in billabongs and floodplains have increased from two to ten times the pre-European rates, but the total volumes remain small, on the order of millimetres per year. Most of this deposition was probably associated with high SS loads in the late 19th century.

\section{SEDIMENT BUDGETS}

We have drawn together published historical and measured records of SS sources and deposition to determine the associations between humans and the river Murray water quality. We now review largescale sediment budgets based on measured loads, on modelled processes, and on isotopic signatures of the sediment. The historical information provides context for these budgets, and the budgets add magnitudes to the patterns identified from the historical information.

\subsection{Measured SS budgets since the 1980s}

The studies by Thoms and Walker $(1992,1993)$ remain the most substantial studies of measured sediment budgets for the upper and lower river Murray, respectively. Using 16 years of SS data at eight stations in the middle and upper reaches of the river Murray, and in three major tributaries, Thoms and Walker (1992) estimated sediment loads (Figure 4). The two reservoirs on the river Murray retained large quantities of sediment, totalling more than 1.47 million tonnes over the 16 years of record. The estimated trap efficiencies were 35\% for Lake Hume and 52\% for Lake Mulwala. 
Suspended sediment in the River Murray

Concentrations of SSCs were highly variable, ranging from 1 to $269 \mathrm{mg} \mathrm{L}^{-1}$. The average annual SS load for the river Murray at Tocumwal, the farthest downstream station, was 134,400 t. This is much less than loads recorded for other semi-arid river systems and may reflect low rainfall erosion potential, low basin relief, and the high trap efficiencies of the two large impoundments. There was considerable variation in annual sediment loads over the 16 years of record, with higher loads during wet years. For instance, at Yarrawonga, 43\% of the 16-year cumulative sediment load was transported in 1974-1975 when sustained major flooding occurred. Channel erosion was considered the single most important contributor of sediment, supplying $69 \%$ of the average annual load, as was discussed above.

For the lower river Murray, Thoms and Walker (1993) analysed sediment storage in the 11 weir pools downstream of the Murray-Darling confluence, concentrating particularly on the two downstream weirs—Locks 2 and 3. They estimated the total sediment input into the reach as $3.2 \times 10^{6} \mathrm{t} \mathrm{year}^{-1}$. Given that the load is just 134,400 t year $^{-1}$ at Tocumwal (above), this means that the river accumulates nearly three million tonnes of sediment below Tocumwal, much of it from the Darling

River. One third of this sediment $\left(1.05 \times 10^{6}\right.$ t year $\left.^{-1}\right)$ is trapped in the upstream weir pools $4-10$ that have trap efficiencies from $4 \%$ to $11 \%$.

\subsection{Sediment sources estimated using isotopic tracers}

Isotopic tracers provide insights into sediment flux in the river. Using isotopic tracers, Wallbrink et al. (1998) concluded that the mean residence times of fine-grained SS within the mid-Murrumbidgee River system was 10 years (+/ -5 years), which was the recurrence interval of moderate-sized floods. Gingele and De Deckker (2005) sampled deposited clay sediments above and below the DarlingMurray junction at Wentworth and used isotopic ratios and a mixing model to demonstrate that 36\% of the sediment came from the Darling River and 64\% from the river Murray. Interestingly, these proportions reflect the ratio of runoff from each catchment, with $32 \%$ of the annual runoff coming from the Darling, even though it makes up over $60 \%$ of the catchment area. Also of interest is that these proportional ratios (1/3 Darling and 2/3 Murray) correspond to the ratio of average SSC predicted by DeRose et al. (2003; $35 \mathrm{mg} \mathrm{L}^{-1}$ for the Murray and $12 \mathrm{mg} \mathrm{L}^{-1}$ for the Darling). 
Suspended sediment in the River Murray

\subsection{Modelled sediment budgets}

Pioneering research combining isotopic sediment tracing, with catchment scale sediment budget modelling, provides more information about the gross sources and sinks of sediment to the river Murray. The focus of the tracing work has been the Murrumbidgee catchment (Olley, 1995; Wallbrink et al., 1998; Olley \& Scott, 2002; Olley \& Wasson, 2003; Prosser et al., 2003), but the rest of the catchment has also been reasonably well modelled (DeRose et al., 2003; Lu et al., 2006). The following summary is derived from this research.

The river Murray catchment has been extensively modelled with the SedNet model. This is a spatially distributed sediment routing model, which predicts lumped average annual sediment loads for subcatchments for pre- and post-European conditions from slopes, gullies, and river banks. The model also estimates bed, floodplain, and reservoir deposition. Results from SedNet (Table 2) suggest that total pre-European sediment delivery to the tributaries of the Murray-Darling system was $0.7 \mathrm{Mt}$ year $^{-1}$, just 3\% of the post-European rate of 28.7 Mt year $^{-1}$. Just over half of the post-European load (16.7 Mt year $^{-1}$ ) was suspended load. Importantly, the model predicts that $13.1 \mathrm{Mt}^{-1}{ }^{-1}$ (78\%) of SS has been trapped on floodplains and a further 3.3 Mt year ${ }^{-1}$ trapped in reservoirs. They predict that just $0.1 \mathrm{Mt}$ year $^{-1}(0.3 \%)$ of the post-European SS now reaches the mouth of the river Murray (Table 2). The MDB is therefore a system of net sediment redistribution rather than net sediment export (DeRose et al., 2003). Despite the huge increase in erosion rates, gross sediment export from the basin, as a whole, appears to have changed little. This is because of the high trap efficiency of dams and weirs in the modern catchment, which is estimated to be 92-95\% (Wilkinson et al., 2009). Note that the modelling does not include sediment from gold mining, so it almost certainly underestimates 19th-century sediment loads.

The models reveal surprising patterns of sediment delivery across the basin. The major areas of erosion in the basin are not the large discharge rivers in the steep, wet, southern basin, but the lowgradient, low-energy catchments of the northern basin including the Murrumbidgee and Lachlan Rivers in NSW and the small streams of the Upper Darling Basin. Hillslope erosion is a major process in these northern catchments, but delivery efficiencies are very low (Lu et al., 2006). Delivery 
Suspended sediment in the River Murray

efficiencies are much higher for gullies, which is why, historically, they have been the main sediment source. River SS loads vary considerably across the basin. In general, they are greatest, typically exceeding 100 and occasionally $400 \mathrm{kt}^{-1}$ year ${ }^{-1}$, along the main reaches of rivers draining the eastern and southern basin margins. In these regions, specific SS yields are equivalent to $10-50 \mathrm{t} \cdot \mathrm{km}^{-2} \cdot \mathrm{year}^{-1}$ and thus low by international standards. Yields decline with distance downstream and are predicted to be below $1 \mathrm{t} \cdot \mathrm{km}^{-2}$. year ${ }^{-1}$ for much of the lowland river network. Overall, $63 \%$ and $18 \%$ of the river network is predicted to have SS loads above 20 and 100 times natural rates, respectively. Regions of the river network with highest loads, together with upland areas having the most soil erosion, are those areas most impacted by increases in SS relative to natural conditions.

The most recent detailed sediment budget analysis considers the Goulburn-Broken River Basin (Victoria's largest catchment; Wilkinson et al., 2009) and validates the above results against measured SS loads (Table 3). Riverbank erosion is predicted to be the largest SS source, with hillslope erosion and gully erosion predicted to be smaller sources. Twenty seven percent of the total SS supplied to the river network is predicted to be exported to the river Murray, and half of the total eroded sediment is predicted to be deposited on floodplains. The deposition rate ( $5 \mathrm{~mm}$ per 100 years) appears to be a much lower rate than measured in the river Murray floodplains (see above), suggesting that export rates could be overestimated in the model. Reservoir deposition is predicted to trap $24 \%$ of the total sediment supply, mainly in the Eildon Reservoir and Goulburn Weir.

What confidence can we have in these models? When comparing the results with SS data, the model efficiency $\mathrm{E}^{*}$ for total yield is 0.84 , which is high. The results are consistent with earlier modelled results (Table 2). Generally, the larger the catchment area, the better the model predictions (Wilkinson, 2008). Comparisons with radionuclide tracer studies indicate that the model predicts the relative contributions of surface and subsurface erosion reasonably well in the temperate Murrumbidgee River catchment (Wallbrink et al., 1998). Note that the models do not consider the following sources and sinks: historical gold mining (considered above), invasive carp, and deposition in low-level weirs anywhere in the system (they only consider trapping in large dams).

\subsection{Sediment delivery to the ocean}


Suspended sediment in the River Murray

The delivery of sediment to the ocean from the MDB is of general interest, especially in light of the one to two orders of magnitude increase in erosion in the catchment. In an influential global review, Milliman and Meade (1983) reported the annual sediment delivery from the river Murray to the ocean to be $30 \mathrm{Mt} \mathrm{year}^{-1}$. This figure is often used in global sediment reviews, but in a later study, they suggest that this figure was a transcription error, and they accept the post-European sediment load of 1 Mt year ${ }^{-1}$ proposed by Wasson et al. (1996). This value is close to that estimated by Thoms and Walker (1993) who estimated an annual sediment load below the Darling Junction of $3.2 \times 10^{6} \mathrm{t}$ year $^{-1}$, but about $1 \times 10^{6}$ t year $^{-1}$ of this was deposited in the 10 weir pools, leaving about $2 \times 10^{6} \mathrm{t}$ year $^{-1}$ to enter Lake Alexandrina. The modelled estimates of delivery to the lower lakes by DeRose et al. (2005) is an order of magnitude smaller again, at just $1 \times 10^{5}$ t. They suggest that there is likely to be little difference in total sediment export from the mouth under pre- and post-European scenarios. However, these modelled scenarios do not consider sediment from historical gold mining or deposition in the terminal lakes and the Coorong. We have described the evidence of large increases in deposition rates in these lakes since European settlement above. The construction of the barrages since 1919 will also have encouraged deposition in the lakes and further limited sediment movement to the mouth (Fuller et al., 2015). Finally, the Murray mouth is now often closed, thereby restricting sediment movement. The mouth closed in 1981, and modelling by Commonwealth Scientific and Industrial Research Organisation (2008) suggests that river regulation has increased cease-to-flow occurrences at the Murray mouth from $1 \%$ of the time under modelled natural flow, to $40 \%$ of the time with water resource development. Hence, very little sediment will be transported across the lakes and through the mouth, except in large floods. Modelling by Shuttleworth et al. (2005) suggests that there is actually a net movement of sediment from the coast into the Murray mouth as a result of reduced river discharge due to human water diversion.

There is little evidence of offshore sediment from the Murray mouth. Schmidt et al. (2010) sampled sediments around the mouth of the river Murray to investigate offshore movement of sediment along the palaeo-Murray canyons. They found that sediments moving down the canyons were almost entirely formed of carbonates and essentially discount any terrigenous detritic contribution from the 
Suspended sediment in the River Murray

river Murray. This is a remarkable conclusion. Australia's largest river basin contributes essentially no sediment to the ocean, despite an order-of-magnitude increase in catchment erosion rates.

\subsubsection{Comparing the river Murray SSC to global rivers}

The river Murray has a reputation as a muddy and turbid river. How does its average SSC compare with large global rivers? Most global literature on river SS concentrates on loads delivered to the ocean. We have established that the river Murray has low SS load and a low rate of delivery to the ocean, but the river also has a low discharge, so there is no particular reason why it should have a correspondingly low SSC. The average SSC for the 221 rivers in the GEMS database (Meybeck \& Ragu, 2012; Figure 8) is around 1,080 $\mathrm{mg} \mathrm{L}^{-1}$, and the median is $188 \mathrm{mg} \mathrm{L}^{-1}$. DeRose et al. (2003) estimated an average, post-European SSC for the river Murray of $35 \mathrm{mg} \mathrm{L}^{-1}$ and $12 \mathrm{mg} \mathrm{L}^{-1}$ for the Darling River. Almost all estimates of average SSC for the river Murray and its larger southern tributaries is below $100 \mathrm{mg} \mathrm{L}^{-1}$ so the river Murray has low SSC for the size of its catchment area (Figure 8). From this data, the mid-reaches of the river Murray are in the bottom 10\% of SSC for large rivers, whereas the lower reaches are in the bottom $25 \%$. Note the logarithmic scale on Figure 8. There is a very similar pattern if discharge is used instead of catchment area. Although there are many large rivers with similarly low SSC, the river Murray can be considered to have globally low SSCs for its catchment area and discharge, even with post European increases.

\section{SYNTHESIS}

In this section, we synthesise the historical, measured, and modelled information about SS in the river Murray. The instrumental record of fine sediment transport (both turbidity and SS) along the river Murray is poor, dating only from the mid-1970s. To understand the SS story before that time, we must rely on historical descriptions, numerical modelling, and most recently, isotopic methods. Using this range of information, a clear story emerges of the post-European history of SS on the river Murray and the delivery of sediment to the ocean. 
Suspended sediment in the River Murray

Overall, the Murray's sediment history can be divided into four periods with specific patterns: Aboriginal (before 1850), the gold and gully period, (1850 to 1890, with effects extending into the 1930s), hiatus (1940s to 1960s), and regulation (1960s to present; Table 4).

\subsection{Aboriginal period (before 1840)}

Human impact on sediment in the river Murray needs to be put into the context of the substantial changes in the character of the river since the Holocene. The sinuous, SS-dominated river we are familiar with is only Holocene in age and replaced a much larger, bedload-dominated system. Aboriginal people lived through these major changes in morphology. There is no evidence that Holocene sediment loads were elevated by Aboriginal catchment burning practices. This contrasts with the clear increase in sediment loads produced by land clearing in New Zealand by pre-European Polynesian settlers (Fuller et al., 2015).

Descriptions of the river at first European contact describe clear water at low flows in the river Murray, but the Darling River seems to have been turbid at all flows. There were many reports of high organic content in the water. Bank erosion rates were low, and sediment was transported from the catchments during floods (usually in winter/spring), with models suggesting that more sediment came from the northern catchments than the southern. Load from the southern catchment would have been highest after major wildfires denuded steep slopes. Low deposition rates on floodplains (around 1/10 of contemporary rates) suggest that sediment concentrations in flood waters were lower than floods of today. Models suggest that sediment load to the ocean was small and almost certainly less than $1 \mathrm{Mt}$ year $^{-1}$.

\subsection{Gold and gully period (1850 to $1890, \sim 1930$ s)}

Increases in SS from gold mining and gullying were roughly coincident from the 1860s, but sediment from gold mining has not been included in sediment budgets in the past, including in modelled budgets. These two sources increased SS at all flows, but particularly at low and medium winter flows when both miners were active, and gullying occurred. There is a shift to more sediment from southern catchments in this period. Overall, this period can be characterised as a time of increasing connectivity in the catchment. Sediment delivery efficiency was increased by incision of swampy 
Suspended sediment in the River Murray

valley floors and gold mining practices. Sediment deposition on floodplains would have been at a maximum in this period, and floodplain wetlands became more turbid. With few dams to trap sediment, we suggest that SSC and loads to the river Murray were at their maximum in this period, probably peaking around the 1870s or 1880s. The relatively rapid recovery from this scale of disturbance (Rustomji \& Pietsch, 2007) can encourage managers that the river system is not irredeemably degraded by sediment changes.

\subsection{Hiatus period (1940s to $1960 \mathrm{~s}$ )}

Sediment from both mining and gullying declined progressively from the 1890s through to the 1930s. A few large dams were constructed by the 1930s (e.g., Hume Dam, Eildon Dam), and more sediment would have been stored in run-of-river weirs than in major dams during this period. There is anecdotal evidence of clear water throughout the basin at this time during low flows.

\subsection{Regulation period (1960s to present)}

The 1970s saw an increase in dam construction for irrigation throughout the catchment. Flow regulation for irrigation dramatically increased in this period leading to long-duration irrigation flows through the summer months in the middle reaches and reduced flows overall in the lower river. The river Murray is now disconnected from sediment supply in its upper catchment by a ring of high trap efficiency dams. River erosion, from riverbanks and eroding effluent channels, has increased with flow regulation. The consequence is a shift in this period from hillslope and upper catchment sources of sediment to channel erosion in the low-land tracts of the river Murray and its tributaries. New sources of in-channel sediment were also introduced at this time: the spread of carp through the catchment by the 1970s and erosion by boat waves. The result is that turbidity in the middle reaches of the river has been increasing by a few percent per year since the 1970s. Most of these processes cause erosion in the summer months. Overall, this period is characterised by disconnection of the river from its catchment (the opposite of the gold and gullies period above). The river is isolated by dams, effluent channels are isolated by regulator gates, and the river is disconnected from its floodplain by artificial levees. 
Suspended sediment in the River Murray

Even with an order-of-magnitude increase in European-derived sediment loads since the 1860s, by global standards, both modelled and measured estimates suggest that the river Murray has both low SSCs, low sediment loads, and a paltry sediment delivery to the ocean. Despite globally normal (or even elevated) catchment erosion rates (particularly by gullies), only a tiny proportion of that sediment reaches the trunk stream. Two thirds of the sediment delivered to the lower Murray comes from the river Murray, and one third from the Darling River. Sediment is stored in wetlands, predominantly on floodplains and in dams. Accretion rates of wetlands and floodplains have increased by 1 to 10 times from the pre-European rates, but these rates peaked in the late 19th century.

\subsection{Implications of this synthesis of SS in the river Murray}

\subsubsection{Biological implications}

Turbid water is a feature of river ecosystems in the MDB (Thoms, 2006) due to the presence of high concentrations of fine suspended particles. Excess fine sediment can alter water chemistry, the textural character of river bed sediment, as well as influence most freshwater biota (Kirk, 1988). Turbidity affects primary production in freshwater ecosystems by influencing the amount of light available to benthic and water column algae for photosynthesis (Davies et al., 2008). As a result of high turbidity, most primary production is restricted to a narrow band along the shallow littoral zone of the river banks across the MDB (Sheldon \& Thoms, 2006). Despite the high natural turbidity of river water, benthic algae have been shown to be an important source of energy in the river ecosystems of the MDB (Bunn et al., 1999). Increasing turbidity or changes in the seasonal character of turbidity levels will significantly influence primary productivity, thus food webs of these river ecosystem systems (Robertson et al., 1999). In addition, the well documented ecological shifts in the floodplain wetlands, from aquatic macrophytes growing in clear water to algae-dominated systems in turbid water (Ogden, 2000), have been attributed to significant changes in fine sediment loads, thus the turbidity environment, of the river Murray (Ogden, 2000; Gell \& Reid, 2014).

Alterations to benthic zone production, as a result of increases in higher turbidity, have recently been implicated in changing the stability of food webs of rivers in the MDB (Thoms \& Delong, 2018).

Substantive changes in the trophic status and food web character were detected between pre- and postEuropean periods in response to multiple stressors by Thoms and Delong (2018). Three lines of 
Suspended sediment in the River Murray

evidence support the conclusion of European period-driven changes in the aquatic food webs of rivers in the MDB. Differences between pre- and post-European periods of disturbance were detected in stable isotope ratios of fish, mussels, and snails; Layman metrics, representing community niche space; and mean trophic position and food chain length (Thoms \& Delong, 2018). Substantial shifts in basal resource contribution overtime is an indicator of a state change and loss of resilience in these rivers (Thoms \& Delong, 2018). One of the main drivers of these changes was changes in water clarity—a factor influenced by turbidity.

\subsubsection{Management implications}

This synthesis has implications for our perception of the river Murray and its management. The normal perception is that post-contact European activities increased SS delivered to the river Murray, and the river has generally been more turbid ever since. There is some truth to this. However, the complexity of sources and timing of sediment delivery to the river has not been laid out before. The dominant source of sediment has shifted from the north to the south and then to the river channel itself. The seasonal variation in turbidity has also probably shifted from winter to summer. These variations need to be considered in reconstructing related biological aspects of the recent history of the river. Overall, the four periods of SS identified here (Aboriginal, gold and gullies, hiatus, and regulation) provide a useful framework for understanding the impact of humans on the river. In particular, the period of low turbidity from the 1940s to the 1960s represented a hiatus in a much longer period of peak Europeanderived sediment concentrations. The river Murray had been subjected to over half a century of high SS loads by this time, and we should be cautious about considering the river at the time of this hiatus period as a target for restoration.

Huge amounts of money are being spent by governments on attempting to return a more pre-European environmental flow regime to the river. Gell and Reid (2016) emphasise that water quality is an equally important focus, and SS is a critical water quality parameter. Although reducing turbidity (and its associated nutrients) is a general goal of river health strategies in both NSW and Victoria, there is no coherent strategy across the catchment. The goal of such a strategy should at least be to return the river to low-summer SSCs found in the 1840s and 1950s. A consequence of this review is that erosion of the channel and effluents of the river Murray itself should be a focus of any such strategy. Note that 
Suspended sediment in the River Murray

catchment sediment models also emphasise the importance of instream erosion sources, but they do not consider the erosion mechanisms emphasised here (regulation, boat waves, and carp). It is more feasible to manage this local erosion than to manage diffuse erosion sources across the whole catchment. In any case, there is now strong evidence that sediment supply from gullies and other catchment sources is declining (Rustomji and Pietsch 2007). A large amount of money is already being spent on erosion control below the Hume Dam, and the consequences of this program for SS loads would be a useful investigation. Another point to note here is that, if irrigation flows are contributing to high sediment loads, this should be considered as an environmental externality of the irrigation industry. The irrigation industry not only produces a reversed seasonality of flows in the river Murray, but a reversed seasonality of elevated SSCs as well.

This synthesis identifies some research gaps. The sediment models developed for the Murray-Darling system are amongst the world's best, but these could be improved by considering sediment from historical gold mining and the in-channel sediment sources from flow regulation, boat wash, and carp. Further, models have not considered the intra-annual patterns of sediment concentrations and loads, particularly seasonality, base flow, and flood peaks. These temporal changes are biologically important, and this study suggests that they have probably changed substantially over the last two centuries. Contemporary deposition of sediment on floodplains is another research area. Reduced flooding (due to flow regulation), flood levees, and regulators on effluents are now disconnecting the river from the floodplains and wetlands. Could sediment and nutrient movement onto floodplains now be too low?

SS (and suspended solids) is a basic water quality parameter. This study has demonstrated that measures of this parameter are poor on Australia's most iconic river. They are not presently sufficient to estimate, for example, sediment loads in the river Murray. Even turbidity measures, which are a useful but inadequate surrogate, are poor across the basin. At the very least, suspended solid measures should be included in the routine measurement suite of the Murray-Darling Basin Authority.

\section{CONCLUSIONS}

The instrumental record of fine sediment transport (both turbidity and SS) along the river Murray is poor, dating only from the mid-1970s. By supplementing this record with historical descriptions, 
Suspended sediment in the River Murray

numerical modelling, and most recently, isotopic methods, a more complicated spatial and temporal pattern of SS emerges. Today, the river Murray delivers about the same, or even less than, the preEuropean sediment load to the ocean. This is a remarkably low SS delivery efficiency given the one to two order-of-magnitude increase in sediment production from the catchment since European settlement. Of the small load delivered to the lower Murray, two thirds of the sediment come from the river Murray, and one third from the Darling River. A large proportion is deposited in wetlands and floodplains, and accretion rates of these areas have increased by 1 to 10 times from the pre-European rates, but the rates are highly variable.

The river Murray's recent sediment history can be divided into four periods with varying source areas, sediment loads, and seasonal patterns. The Aboriginal period (before 1840) was characterised by clear water at summer low flows in the river Murray, with more sediment coming from the northern catchment than the southern, and the Darling River seems to have been turbid at all flows. There is no evidence that Aboriginal burning resulted in any measurable increase in SS in rivers. The peak of SS supply to the river Murray occurred between 1860s and the 1890s, during the gold and gullies period. This period saw huge increases in sediment delivery efficiency as valley floors were incised by gullies, and gold sluicing flushed huge amounts of sludge into streams. The role of gold mining in increasing SS loads in the river Murray has not been appreciated in the past, but it was almost certainly comparable to other forms of erosion, and the main source was from southern (Victorian) tributaries. This was a period of increased catchment connection. Sedimentation in billabongs and floodplains increased by double or more, and the biota in billabongs switched to turbid communities. By the 1930s, sediment supply from gullies and gold mining waned. Up to the 1960s, SS loads declined across the basin. Many people recall the clear water of this hiatus period and think of it as the "natural” river, despite the preceding half century of elevated sediment loads. Dam construction and flow regulation through the 1960s and 1970s (the regulation period) disconnected the river Murray from catchment sediment. Catchment sediment supply switched to instream sediment sources as increasing durations of summer irrigation flows eroded the channel and its effluents. In-channel sources were exacerbated by the spread of carp through the network and from wave erosion from water skiing. The regulation period can be thought of as a period of disconnection from the catchment. The proportion of sediment transported in summer increased. 
Suspended sediment in the River Murray

There is a huge investment in the MDB for providing environmental water. It is appropriate to focus some attention on the SS quality of that water. A management target for such a program would be to reduce summer turbidity to pre-European levels by addressing in-channel sediment sources in the river Murray itself.

\section{DEDICATION}

This special edition of River Research and Application, and this paper, is dedicated to our friend and colleague Professor Wayne Erskine.

\section{ACKNOWLEDGEMENTS}

The genesis of this paper was an invited presentation given to a conference organised by the "Centre for the Inland,” La Trobe University. The research was supported by Australian Research Council Grant DP160100799 “Rivers of Gold”. Detailed reviews by Elyssa De Carli, Ian Fuller, and an anonymous reviewer have substantially improved this paper, and we appreciate their dedication.

\section{REFERENCES}

Asselman, N. E. (1999). "Suspended sediment dynamics in a large drainage basin: The river Rhine." Hydrological processes 13(10): 1437-1450.

Beveridge, P. (1883). "Of the aborigines inhabiting the great lacustrine and riverine depressions of the lower Murray, Lower Murrumbidgee, Lower Lachlan, and Lower Darling." Journal and Proceedings of the Royal Society of New South Wales 17: 19-74.

Bowler, J. M., H. Johnston, J. M. Olley, J. R. Prescott, R. G. Roberts, W. Shawcross and N. A. Spooner (2003). "New ages for human occupation and climatic change at Lake Mungo, Australia." Nature 421(6925): 837, 840, DOI: 10.1038/nature01383. 
Suspended sediment in the River Murray

Bowman, D. (1998). "The impact of aboriginal landscape burning on the Australian biota." The New Phytologist 140(3): 385-410.

Brady, E. J. (1911). River rovers. Melbourne, George Robertson and Company Pty Ltd.

Broughton, G. W. (1966). Men of the Murray: A surveyor's story. Adelaide, Rigby Limited.

Bunn, S., P. Davies and T. Mosisch (1999). "Ecosystem measures of river health and their response to riparian and catchment degradation." Freshwater biology 41(2): 333-345.

Butzer, K. W. and D. M. Helgren (2005). "Livestock, land cover, and environmental history: The tablelands of New South Wales, Australia, 1820-1920." Annals of the Association of American Geographers 95(1): 80-111.

Cadwallader, P. and P. Rogan (1977). "The Macquarie perch, Macquria australasica (Pisces: Percichthyidae), of Lake Eildon, Victoria." Australian Journal of Ecology 2(4): 409418.

Clark, I. D. (1988). The Port Phillip Journals of George Augustus Robinson: 8 March-7 April 1842 and 18 March - 29 April 1843., Department of Geography Monash University, Melbourne.

Clark, I. D., Ed. (2000). The Journals of George Augustus Robinson, Chief Protector, Port Phillip Aboriginal Protectorate, Volume 1: January 1839-30 September 1840. Ballarat, Clarendon Heritage Matters.

CSIRO (2008). Water availability in the ovens: A report to the Australian government from the CSIRO Murray-Darling Basin Sustainable Yields Project, Commonwealth Scientific and Industrial Research Organisation.

Curr, E. M. (1965). Recollections of squatting in Victoria. Then called the Port Phillip District (from 1841-1851). Abridged with a foreward and notes by Harley W. Forster. Carlton, Victoria, Melbourne University Press.

Davies-Colley, R. and D. Smith (2001). "Turbidity suspended sediment, and water clarity: A review 1." Journal of the American Water Resources Association 37(5): 1085-1101. 
Suspended sediment in the River Murray

Davies, P., J. Harris, T. Hillman and K. Walker (2010). "The sustainable rivers audit: Assessing river ecosystem health in the Murray-Darling Basin, Australia." Marine and Freshwater Research 61(7): 764-777.

Davies, P., S. Lawrence and J. Turnbull (2011). "Harvesting water on a Victorian colonial goldfield." Australasian Historical Archaeology: 24-32.

Davies, P. M., S. E. Bunn and S. K. Hamilton (2008). Primary production in tropical streams and rivers. Tropical stream ecology, Elsevier: 23-42.

Davis, J., I. Rutherfurd and B. Finlayson (1997). "Reservoir sedimentation data in south-eastern Australia." Water 24: 11-15.

DeRose, R., D. Barrett, A. Marks, Y. Chen, D. Simon, L. Lymburner, G. Douglan and M. Palmer (2005). "Regional patterns of riparian vegetation, erosion and sediment transport in the Ovens River Basin."

DeRose, R., I. Prosser and M. Weisse (2004). "Patterns of erosion and sediment transport in the Murray-Darling Basin." IAHS Publication (International Association of Hydrological Sciences) 288: 245-252.

DeRose, R., I. Prosser, M. Weisse and A. Hughes (2003). Patterns of erosion and sediment and nutrient transport in the Murray-Darling Basin. Technical Report 32/03, CSIRO Land and Water, Canberra.

Dosseto, A., P. Hesse, K. Maher, K. Fryirs and S. Turner (2010). "Climatic and vegetation control on sediment dynamics during the last glacial cycle." Geology 38(5): 395-398.

Dosseto, A., S. Turner and G. Douglas (2006). "Uranium-series isotopes in colloids and suspended sediments: Timescale for sediment production and transport in the Murray-Darling River system." Earth and Planetary Science Letters 246(3-4): 418-431.

Erskine, W., I. Rutherfurd, J. Sherrard and J. Tilleard (1993). Investigation of river channel changes. River Murray and Anabranches between Hume Dam and Lake Mulwala, Canberra: Murray-Darling Basin Commission.

This article is protected by copyright. All rights reserved. 
Suspended sediment in the River Murray

Finniss, B. T. (1853). Journal kept by Boyle Travers Finniss During the Trip up the River Murray on the "Lady Augusta", August 1853. MS 8256 Box 9/2. State Library of Victoria. Melbourne.

Frawley, J., S. Nichols, H. Goodall and E. Baker (2011). Murray: Talking fish-Making connections with the rivers of the Murray-Darling Basin. M. D. B. Authority. Canberra.

Fuller, I. C., M. G. Macklin and J. M. Richardson (2015). "The geography of the Anthropocene in New Z ealand: Differential river catchment response to human impact." Geographical Research 53(3): 255-269.

Gale, S. and R. Haworth (2002). "Beyond the limits of location: Human environmental disturbance prior to official European contact in early colonial Australia." Archaeology in Oceania 37(3): 123-136.

Gallant, A. J. and J. Gergis (2011). "An experimental streamflow reconstruction for the River Murray, Australia, 1783-1988." Water Resources Research 47(12).

Gell, P., J. Fluin, J. Tibby, G. Hancock, J. Harrison, A. Zawadzki, D. Haynes, S. Khanum, F. Little and B. Walsh (2009). "Anthropogenic acceleration of sediment accretion in lowland floodplain wetlands, Murray-Darling Basin, Australia." Geomorphology 108(1-2): 122-126.

Gell, P., J. Fluin, J. Tibby, D. Haynes, S. Khanum, B. Walsh, G. Hancock, J. Harrison, A. Zawadzki and F. Little (2006). "Changing fluxes of sediments and salts as recorded in lower River Murray wetlands, Australia." IAHS Publication (International Association of Hydrological Sciences) 306: 416.

Gell, P. and M. Reid (2014). "Assessing change in floodplain wetland condition in the Murray Darling Basin, Australia." Anthropocene 8: 39-45.

Gell, P., J. Tibby, F. Little, D. S. Baldwin and G. Hancock (2007). "The impact of regulation and salinisation on floodplain lakes: The lower river Murray, Australia." Hydrobiologia 591: 135-146.

This article is protected by copyright. All rights reserved. 
Suspended sediment in the River Murray

Gell, P. A. and M. A. Reid (2016). "Muddied waters: The case for mitigating sediment and nutrient flux to optimize restoration response in the Murray-Darling basin, Australia." Frontiers in Ecology and Evolution 4: 16.

Gillson, L. and K. J. Willis (2004). "‘As Earth's testimonies tell’: Wilderness conservation in a changing world." Ecology Letters 7(10): 990-998.

Gingele, F. and P. De Deckker (2005). "Clay mineral, geochemical and Sr-Nd isotopic fingerprinting of sediments in the Murray-Darling fluvial system, southeast Australia." Australian Journal of Earth Sciences 52(6): 965-974.

Gingele, F. X. and P. de Deckker (2007). "Late Pleistocene and Holocene climate of SE Australia reconstructed from dust and river loads deposited offshore the river Murray mouth." Earth and Planetary Science Letters 255(3-4): 257-272.

Gippel, C. J. and D. Blackham (2002). Review of environmental impacts of flow regulation and other water resource developments in the river Murray and lower Darling River system, Murray Darling Basin Commission.

Green, S. J. (1999). Drawdown and river bank stability. Master of Engineering Science thesis, University of Melbourne.

Hamilton, G. (1845). A Journal of an Overlander and A Narrative of Journies in New South Wales and South Australia from 1836-1845 with illustrations. George Hamilton. National Library of Australia, MS 4299C.: 1-73.

Harris, W. J. (1938). "The Physiography of the Echuca District." Proceedings of the Royal Society of Victoria 51: 45-60.

Hart, B. T. (2016). "The Australian Murray-Darling basin plan: challenges in its implementation (part 1)." International Journal of Water Resources Development 32(6): 819-834.

Henderson, B., Y. Liu and D. Baldwin (2013). Trends in physical and chemical aspects of water quality in the Murray-Darling Basin 1978-2012, CSIRO Water for a Healthy Country Flagship, Australia. Note: Appendices exist as separate report under the same name. 
Suspended sediment in the River Murray

Hodgkinson, C. (1856). Report on the Murray River District, in Reference to its Geology, Soil, Prospective Resources, Proposed Means of Inter-communication, etc., Submitted to the Honorable the Surveyor General in Accordance with his Instructions of 1st April, 1856.: 13 .

Hovell, W. H. and H. Hume. (1824). "Journey of Discovery to Port Phillip, New South Wales by Messers, W.H. Hovell and Hamilton Hume in 1824 and 1825." Retrieved 22 October 2014.

Hughes, A. O. and I. Prosser (2003). Gully and riverbank erosion mapping for the Murray-Darling Basin, Citeseer.

Hughes, P. and M. Sullivan (1981). "Aboriginal burning and late Holocene geomorphic events in eastern NSW." Search 12(8): 277-278.

Hume, H. (1831). An Extract from the Journal of Mr. Hamilton Hume, written on a Tour through the interior to Bass' Straits, in the Year 1824. Sydney Herald (NSW).

Jevons, W. S. (1859). The Murray River. Border Post.

Kemp, J. and E. Rhodes (2010). "Episodic fluvial activity of inland rivers in southeastern Australia: Palaeochannel systems and terraces of the Lachlan River." Quaternary Science Reviews 29(5-6): 732-752.

Kenyon, C. and I. D. Rutherfurd (1999). "Preliminary evidence for pollen as an indicator of recent floodplain accumulation rates and vegetation changes: The Barmah-Millewa Forest, SE Australia." Environmental Management 24(3): 359-367, DOI: 10.1007/s002679900239.

King, A., A. Robertson and M. Healey (1997). "Experimental manipulations of the biomass of introduced carp (Cyprinus carpio) in billabongs. I. Impacts on water-column properties." Marine and Freshwater Research 48(5): 435-443. 
Suspended sediment in the River Murray

Kinloch, A. E. (1856). Journal of a Voyage on the Murray, being a Journal of the Voyage of the "Lady Augusta" Steamer from the Goolwa, in South Australia, to Gannewarra, above Swan Hill, Victoria. London, Hope \& Co.

Kirk, J. T. O. (1988). "Optical water quality—What does it means and how should we measure it? ." Journal of the Water Pollution and Control Federation 60: 194-197.

Koehn, J., A. Brumley and P. Gehrke (2000). Managing the impacts of carp, Bureau of Rural Sciences.

Koehn, J., C. Todd, L. Thwaites, I. Stuart, B. Zampatti, Q. Ye, A. Conallin, L. Dodd and K. Stamation (2016). Managing flows and carp, Arthur Rylah Institute for Environmental Research, Department of Environment .... .

Koehn, J., C. Todd, L. Thwaites, I. Stuart, B. Zampatti, Q. Ye, A. Conallin, L. Dodd and K. Stamation (2016). Managing flows and carp. Technical Report Series, Arthur Rylah Institute for Environmental Research, Department of Environment, Land, Water and Planning, Heidelberg, Victoria. 255.

Koehn, J. D. (2004). "Carp (Cyprinus carpio) as a powerful invader in Australian waterways." Freshwater biology 49(7): 882-894.

Leblanc, M., S. Tweed, A. Van Dijk and B. Timbal (2012). "A review of historic and future hydrological changes in the Murray-Darling Basin." Global and planetary change 80: 226-246.

Lu, H., C. J. Moran and I. P. Prosser (2006). "Modelling sediment delivery ratio over the Murray Darling Basin." Environmental Modelling \& Software 21(9): 1297-1308.

Lunt, I. D. (2002). "Grazed, burnt and cleared: how ecologists have studied century-scale vegetation changes in Australia." Australian Journal of Botany 50(4): 391-407.

Lynch, A., J. Beringer, P. Kershaw, A. G. Marchall, S. Mooney, N. Tapper, C. Turney and S. Van der Kaars (2007). "Using the paleorecord to evaluate climate and fire interactions in Australia." Annual Review of Earth and Planetary Sciences 35: 215-239. 
Suspended sediment in the River Murray

Mackay, N., T. Hillman and J. Rolls (1988). Water quality of the river Murray: Review of monitoring 1978 to 1986, Murray-Darling Basin Commission.

Maheshwari, B., K. Walker and T. McMahon (1995). "Effects of regulation on the flow regime of the river Murray, Australia." Regulated Rivers: Research \& Management 10(1): 15-38.

McCoane, J. and T. Murray (1906). Loddon River Pollution Sludge Abatement Board Report. Bendigo, Victoria.

MDBA (2017). Bank erosion along the Murray River between Hume Dam and the Ovens Junction. Canberra, Murray Darling Basin Authority.

Meade, R. H. and J. A. Moody (2010). "Causes for the decline of suspended-sediment discharge in the Mississippi River system, 1940-2007." ydrological Processes: An International Journal 24(1): 35-49.

Meybeck, M. and A. Ragu (2012). GEMS-GLORI world river discharge database, PANGAEA.

Milliman, J. D. and R. H. Meade (1983). "World-wide delivery of river sediment to the oceans." The Journal of Geology 91(1): 1-21.

Mitchell, T. L. (1839). Three expeditions into the interior of Eastern Australia (Volume II).

Moran, C., I. Prosser, R. DeRose, H. Lu, B. Croke, A. Hughes, J. Olley and G. Cannon (2005).

"Sediments and nutrients in the rivers of the Murray-Darling Basin. Targeting the Future." Murray-Darling Basin Commission: Canberra.

Norris, R. H., P. Liston, N. Davies, J. Coysh, F. Dyer, S. Linke, I. Prosser and B. Young (2001). "Snapshot of the Murray-Darling Basin river condition." Murray-Darling Basin Commission, Canberra.

Ogden, R. (2000). "Modern and historical variation in aquatic macrophyte cover of billabongs associated with catchment development." Regulated Rivers: Research and Management 16: 497-512.

This article is protected by copyright. All rights reserved. 
Suspended sediment in the River Murray

Ogden, R. W. (2000). "Modern and historical variation in aquatic macrophyte cover of billabongs associated with catchment development." Regulated Rivers: Research \& Management 16(5): 497-512.

Olive, L. J. and J. M. Olley (1997). "River regulation and sediment transport in a semiarid river: The Murrumbidgee River, New South Wales, Australia." IAHS Publication (International Association of Hydrological Sciences) 245: 283-290.

Olley, J. M. (1995). Sources of suspended sediment and phosphorus to the Murrumbidgee River, Consultancy Report. Division of Water Resources. CSIRO Australia.

Olley, J. M. and A. Scott (2002). Sediment supply and transport in the Murrumbidgee and Namoi Rivers since European settlement, CSIRO Land and Water Canberra.

Olley, J. M. and R. J. Wasson (2003). "Changes in the flux of sediment in the Upper Murrumbidgee catchment, Southeastern Australia, since European settlement." Hydrological processes 17(16): 3307-3320.

Oxley, J. (1818). Journals of Two Expeditions into the Interior of New South Wales, by order of the British Government in the years 1817-18.

Page, K., J. Kemp and G. C. Nanson (2009). "Late Quaternary evolution of riverine plain paleochannels, southeastern Australia." Australian Journal of Earth Sciences 56(S1): S19-S33.

Peterson, L. (1996). Reading the landscape: Documentation and analysis of a relict feature of land degradation in the Bendigo District, Victoria. Melbourne, Department of Geography and Environmental Science.

Portenga, E., D. Rood, P. Bishop and P. Bierman (2016). "A late Holocene onset of aboriginal burning in southeastern Australia." Geology 44(2): 131-134.

Portenga, E. W., K. E. Westaway and P. Bishop (2016). "Timing of post-European settlement alluvium deposition in SE Australia: A legacy of European land-use in the Goulburn Plains." The Holocene 26(9): 1472-1485.

This article is protected by copyright. All rights reserved. 
Suspended sediment in the River Murray

Prendergast, A., J. Bowler and M. Cupper (2009). "Late Quaternary environments and human occupation in the Murray River Valley of northwestern Victoria." New Directions in Archaeological Science 28: 55.

Prosser, I. (1990). "Fire, humans and denudation at Wangrah Creek, southern Tablelands, NSW." Australian Geographical Studies 28(1): 77-95.

Prosser, I., C. J. Moran, H. Lu, J. Olley, R. DeRose, G. Cannon, B. Croke, A. Hughes, A. Jakeman and L. Newham (2003). Basin-wide mapping of sediment and nutrient exports in dryland regions of the Murray-Darling Basin. Technical Report 33/03, CSIRO Land and Water.

Reid, M., J. Fluin, R. Ogden, J. Tibby and P. Kershaw (2002). "Long-term perspectives on human impacts on floodplain-river ecosystems, Murray-Darling Basin, Australia." Internationale Vereinigung für theoretische und angewandte Limnologie: Verhandlungen 28(2): 710-716.

Reid, M., C. Sayer, A. Kershaw and H. Heijnis (2007). "Palaeolimnological evidence for submerged plant loss in a floodplain lake associated with accelerated catchment soil erosion (Murray River, Australia)." Journal of Paleolimnology 38(2): 191-208.

Reid, M. A. and R. W. Ogden (2009). "Factors affecting diatom distribution in floodplain lakes for the Southeast Murray Basin, Australia and implications for palaeolimnological studies." Journal of Paleolimnology 41(3): 453-470.

Reid, M. A., C. D. Sayer, A. P. Kershaw and H. Heijnis (2007). "Palaeolimnological evidence for submerged plant loss in a floodplain lake associated with accelerated catchment soil erosion (Murray River, Australia)." Journal of Palaeolimnology 38(2): 191-208.

Reinfelds, I., E. Swanson, T. Cohen, J. Larsen and A. Nolan (2014). "Hydrospatial assessment of streamflow yields and effects of climate change: Snowy Mountains, Australia." Journal of hydrology 512: 206-220.

This article is protected by copyright. All rights reserved. 
Suspended sediment in the River Murray

RMSNSW (2017). Draft River Murray (Corowa to Ovens River) Erosion Management Plan: Management of boating wash and riverbank erosion. Canberra, Roads and Maritime Services, NSW Government and Murray Darling Basin Commission: 31.

Robertson, A., S. Bunn, P. Boon and K. F. Walker (1999). "Sources, sinks and transformations of organic carbon in Australian floodplain rivers." Marine and Freshwater Research 50(8): 813-829.

Rustomji, P. and T. Pietsch (2007). "Alluvial sedimentation rates from southeastern Australia indicate post-European settlement landscape recovery." Geomorphology 90(1-2): 73-90.

Rutherfurd, I., P. Davies, J. Turnbull and S. Lawrence (2016). The missing volume: How much sediment did historical gold mining release into Victorian rivers? Proceedings of the 8th Australian Stream Management Conference. . G. J. Vietz, Flatley, A.J. and Rutherfurd, I.D. (2016) Leura, New South Wales.: 342-350.

Schmidt, S., P. De Deckker, H. Etcheber and S. Caradec (2010). "Are the Murray Canyons offshore southern Australia still active for sediment transport?" Geological Society, London, Special Publications 346(1): 43-55.

Scott, A. C. (2001). Water erosion in the Murray-Darling Basin: Learning from the past, CSIRO Land and Water Canberra, Australia.

Sheldon, F. and M. Thoms (2006). "In-channel geomorphic complexity: The key to the dynamics of organic matter in large dryland rivers?" Geomorphology 77(3-4): 270-285.

Shuttleworth, B., A. Woidt, T. Paparella, S. Herbig and D. Walker (2005). "The dynamic behaviour of a river-dominated tidal inlet, River Murray, Australia." Estuarine, Coastal and Shelf Science 64(4): 645-657.

Sinclair, P. G. (2001). The Murray: A river and its people, Melbourne University Press.

Sludge Abatement Board (1906-1919). Annual Reports of the Sludge Abatement Board. Melbourne, Parliament of Victoria.

Stapylton, G. C. (1836). Granville Stapylton's 1836 Journal: Volume 1. April 1836.

This article is protected by copyright. All rights reserved. 
Suspended sediment in the River Murray

Sturt, C. (1833). Two expeditions into the Interior of Southern Australia, during the years 1828, 1829, 1839, and 1831: With Observations on the Soil, Climate, and General Resources of the Colony of New South Wales. Volume II. Adelaide, Smith, Elder and Co. Public Library of South Australia.

Sturt, C. (1838). The Unpublished Journal of Charles Sturt's 1838 Overlanding Expedition to Adelaide Following the Hume River. Charles Sturt Papers MS 9025 (photocopy), Held at the State Library Victoria.

Thoms, M. (1995). "The impact of catchment development on a semiarid wetland complex: The Barmah Forest, Australia." IAHS Publication (International Association of Hydrological Sciences) 230: 121-130.

Thoms, M. and M. Delong (2018). "Ecosystem responses to water resource developments in a large dryland river." Water Resources Research.

Thoms, M., J. Foster and B. Gawne (2000). "Flood-plain sedimentation in a dryland river: The River Murray, Australia." IAHS Publication (International Association of Hydrological Sciences)(263): 227-236.

Thoms, M. and K. Walker (1993). "Channel changes associated with two adjacent weirs on a regulated lowland alluvial river." Regulated Rivers: Research \& Management 8(3): 271-284.

Thoms, M. and K. F. Walker (1992). Sediment transport in a regulated semi-arid river: The River

Murray of Australia. aquatic ecosystems in semi-arid regions: Implications for resource management, Saskatoon, Environment Canada, NHRI Symposium.

Thoms, M. C. (2006). "Variability in riverine ecosystems." River research and applications 22(2): 115-121.

Thoms, M. C. (2007). "The distribution of heavy metals in a highly regulated river: The River Murray, Australia." IAHS Publication (International Association of Hydrological Sciences) 314: 145.

This article is protected by copyright. All rights reserved. 
Suspended sediment in the River Murray

Trueman, W. T. (2011). True tales of the trout cod: river histories of the Murray-Darling Basin, Murray-Darling Basin Authority.

Vilizzi, L., L. A. Thwaites, B. B. Smith, J. M. Nicol and C. P. Madden (2014). "Ecological effects of common carp (Cyprinus carpio) in a semi-arid floodplain wetland." Marine and Freshwater Research 65(9): 802-817.

Walker, K. F. and T. Hillman (1977). Limnological survey of the River Murray in relation to AlburyWodonga, 1973-1976, Albury-Wodonga Development Corporation and Gutteridge Haskins \& Davey.

Wallbrink, P., A. Murray, J. Olley and L. Olive (1998). "Determining sources and transit times of suspended sediment in the Murrumbidgee River, New South Wales, Australia, using fallout 137Cs and 210Pb." Water Resources Research 34(4): 879-887.

Wang, H., Z. Yang, Y. Wang, Y. Saito and J. P. Liu (2008). "Reconstruction of sediment flux from the Changjiang (Yangtze River) to the sea since the 1860s." Journal of Hydrology 349(3-4): 318-332.

Wasson, R., L. Olive and C. Rosewell (1996). Rates of erosion and sediment transport in Australia. Erosion and sediment yield: Global and regional perspectives: Proceedings of an international symposium held at Exeter, UK, from.

Wilkinson, S. N. (2008). "Testing the capability of a sediment budget model for targeting remediation measures to reduce suspended-sediment yield." IAHS Publication (International Association of Hydrological Sciences) 325: 559.

Wilkinson, S. N., I. P. Prosser, P. Rustomji and A. M. Read (2009). "Modelling and testing spatially distributed sediment budgets to relate erosion processes to sediment yields." Environmental Modelling \& Software 24(4): 489-501.

Wilson, E. (1859). Rambles in the antipodes: A series of sketches of Moreton Bay, New Zealand, The Murray River and South Australia and the Overland Route. London, W.H. Smith and Son.

This article is protected by copyright. All rights reserved. 
FIGURE 1. River Murray and its major tributaries, with locations and features mentioned in the text. Black bars show location of low-level weirs, and crosses show the major dams. The dotted line represents the edge of the Riverine Plain

FIGURE 2. The red line is the annual volume of alluvium produced from gold mining $\left(\mathrm{m}^{3}\right)$ in Victoria from 1859 to 1891 (most of it from tributaries of the river Murray), and the black line is the increase through time in the volume of alluvium produced per ounce of gold recovered (Redrafted from data in Davies et al., 2018)

FIGURE 3. Comparing suspended sediment (SS) concentrations against discharge, in the Ovens River (brown diamonds) measured by the Sludge Abatement Board during part of the gold dredging period 1906-1914, compared with modern SS measured in the upper Ovens (red triangles) and downstream near the Murray junction (blue squares). During the dredging period, for the same discharge, the Ovens and its tributaries were carrying one to three orders of magnitude more sediment than the present river. Sediment concentrations during the gold period declined downstream, whereas they now increase downstream

FIGURE 4. Sediment budget for the middle river Murray made up of contributions from its major tributaries and the Hume Reservoir, for the 
irrigation (summer) and non-irrigation periods for the record from 1974 to 1989 (Redrafted from Thoms \& Walker, 1992)

FIGURE 5. Turbidity (solid lines) and flow (dotted line) during the 1992 flood at the Cobram (upstream) and Tocumwal (downstream) gauges (Modified from fig. 2 of O'Donnell et al., 1996). Red dashed lines show each discharge peak. The increase in turbidity at the downstream site demonstrates that the channel itself is the source of sediment

FIGURE 6. (a-Left) Bank erosion caused by wave wash from water skiing boats (near Corowa) (Source: Murray-Darling Basin Authority, 2017). (b-Right) Typical bank erosion along the regulated river Murray

FIGURE 7. Mean turbidity (blue line) for the river Murray and southern tributaries 1978-2012 (Data from Henderson et al., 2013). Also showing turbidity trend (orange line) in percentage change per annum 1978-2012. Downstream to the right. Measuring stations/tributaries as follows: Tallandoon/Mitta Mitta River, Bandiana/Kiewa River, Peechelba/Ovens River, Kerang/Loddon River, and Capels Flume/Barr Creek

FIGURE 8. Comparison of the mean total suspended solids concentrations in the river Murray (green triangles from lowest to highest are Jingellic, Tocumwal, and Rufus River stations progressing downstream), major southern tributaries of the river Murray (red diamonds), and 221 global rivers (blue dots; source of global 
Suspended sediment in the River Murray

data: GEMS-GLORI world river discharge database; Meybeck \& Ragu, 2012;

https://doi.org/10.1594/PANGAEA.804574). Note the log-log scale

\section{TABLE 1. Chronological summary of human impacts on suspended sediment in the river Murray Basin}

Indigenous $\quad$ Fire: Changed land cover over millennia

Post $1840 \quad$ Fire regimes changed in frequency, intensity and season. Increase in erosion rate throughout the Murray-Darling Basin

1840-1920 Clearing, drainage and gullying: European squatters, introduction of sheep, and cattle. Coincident with gold mining, population expansion, agriculture, forest clearing, and swamp and floodplain drainage Increase in erosion and sediment delivery throughout the Murray-Darling Basin

1851-1930 Gold mining: Quickly spreads throughout the basin by 1860 Huge increase in sediment supply mainly from the southern basin-Upper Murray, Kiewa, Ovens, Loddon, and Campaspe Rivers

1864-1869 Desnagging: Murray River between Albury and Echuca— $\longrightarrow 3,000$ large snags were removed. Wood removal would have increased in-channel sediment movement throughout the river length.

1870-1898 Flow confinement: Effluent channels blocked and flood levees constructed especially after 1870 “Great Flood.” By 1898, Echuca to Swan Hill works blocked floodwaters on Victoria side to maintain freshwater lakes.

Flow concentrated in channel, increased sediment transport, reduced water losses to floodplain

This article is protected by copyright. All rights reserved. 
Suspended sediment in the River Murray

1880

1919-1939

$1914-1940$

1917-present

1970-present

1950s-

present

1960s-
Desnagging: River Murray was cleared of the largest logs (Trueman, 2011). Wood removal would have increased in-channel sediment movement throughout the river length and along most of river Murray and lowland tributary sections.

Weirs: 13 low-level, run-of-river weirs. Initially for river navigation, now maintain hydraulic head for irrigation channels. Between Albury and Darling River junction: Torrumbarry Weir (1919), Euston Weir and Lock 11, Yarrawonga Weir (1939), and 10 downstream of the Darling Junction

Trap sediment by converting approximately hundred kilometres of riverine environment into a lake

Barrages: Five barrages (weirs), totalling $7.6 \mathrm{~km}$ in length, constructed between the terminal Lakes Alexandrina and Albert and the coastal embayment, the Coorong (Sim \& Muller, 2004) to restrict tidal flux into the lakes and maintain freshwater in the lakes. The effect: to trap more sediment in the lower lakes

Major dams and flood mitigation: Hume Weir (1936) for flood mitigation and summer irrigation water. Forty large ( $>15 \mathrm{~m}$ ) dams on every major river Murray tributary except the Ovens River by 1970s. 1970s: Dartmouth Dam (1979) on Mitta Mitta River, the largest. Major levee systems constructed

Sediment trapped and altered flow regimes over the entire catchment

Irrigation: Increasing proportion of irrigation flows and long-duration releases below Hume Dam reversed flow seasonality. Substantial flows diverted into Upper Murray from Snowy Mountains Inter-basin transfer project. High, long-duration flows increase channel erosion rates from Albury to Yarrawonga. Below there, reduced discharges are the main effect.

Water skiing: Waves from water skiing erodes banks. Entirely concentrated in summer months coinciding with long-duration irrigation flows resulting in increased bank erosion along the river, especially the Tocumwal reach Carp: Introduction of invasive carp, especially spread throughout catchment from 
Suspended sediment in the River Murray

present Victoria after the 1973 flood. Direct increase in mobilising suspended sediment 1970 Desnagging: Major desnagging (over 20,000 logs) project between Hume Dam and Yarrawonga Weir to increase flow conveyance (Gippel et al., 1992). Wood removal would have increased in-channel sediment movement mostly between Hume Dam and Yarrawonga.

TABLE 2. Sediment budget for the Murray-Darling Basin (DeRose et al., 2003)

Sediment budget item Predicted mean annual rate (Mt year $\left.{ }^{-1}\right)$

Suspended 8.4

4.6

16.5

13.1

0

0.1

Bedload

Hillslope delivery

4

0

Gully erosion rate

6

7.0

Riverbank erosion rate

Total sediment supply

Flood plain deposition

Reservoir deposition

Total bed accumulation

Sediment export

0

Natural

0.3

TABLE 3. Predicted sediment budget (inputs and outputs) for the Goulburn Broken catchment (Wilkinson et al., 2009)

$\begin{array}{lclr}\text { Sediment inputs } & \mathrm{Kt} \mathrm{year}^{-1} & \text { Sediment outputs } & \mathrm{Kt} \mathrm{year}^{-1} \\ \text { Suspended sediment } & 110(33 \%) & \text { Floodplain suspended } & 160(48 \%) \\ \text { from hillslopes } & & \text { sediment }\end{array}$


Suspended sediment in the River Murray

Suspended sediment

from gullies

Suspended sediment

from riverbanks

Total inputs
75 (22\%)

$143(44 \%)$

328
Reservoir suspended

sediment

Export suspended

sediment

Total outputs
$78(24 \%)$

$90(27 \%)$

328

TABLE 4 Summary of the suspended sediment loads, sources, and season for each of the four periods

Period/character

1. Aboriginal

2. Gold and gullies
Sediment load

Sediment
source

Catchment surface
Small stream
channels

Sediment

source region

Northern

tributaries

$$
\begin{aligned}
& \text { Northern } \\
& \text { tributaries for } \\
& \text { gullies, } \\
& \text { southern for } \\
& \text { gold }
\end{aligned}
$$

3. Hiatus

Low

$$
\begin{gathered}
\text { Small stream } \\
\text { channels }
\end{gathered}
$$

High

\section{Channel and} effluents of the river Murray
Northern tributaries

Upper reaches

of the lowland river
Sediment

season

Winter floods

Winter low

flows \& floods

Winter floods

Summer

regulated

flows, winter

floods 


\section{University Library}

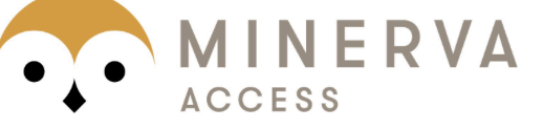

A gateway to Melbourne's research publications

Minerva Access is the Institutional Repository of The University of Melbourne

Author/s:

Rutherfurd, ID;Kenyon, C;Thoms, M;Grove, J;Turnbull, J;Davies, P;Lawrence, S

Title:

Human impacts on suspended sediment and turbidity in the River Murray, South Eastern Australia: Multiple lines of evidence

Date:

2020-02-05

\section{Citation:}

Rutherfurd, I. D., Kenyon, C., Thoms, M., Grove, J., Turnbull, J., Davies, P. \& Lawrence, S. (2020). Human impacts on suspended sediment and turbidity in the River Murray, South Eastern Australia: Multiple lines of evidence. RIVER RESEARCH AND APPLICATIONS, 36 (4), pp.522-541. https://doi.org/10.1002/rra.3566.

Persistent Link:

http://hdl.handle.net/11343/275376 